\title{
Unwelcome? English as a Medium of Instruction (EMI) in the Arabian Gulf
}

\author{
Qais S. Ahmadi ${ }^{1}$ \\ ${ }^{1}$ Education Department, University of Maryland, University College (UMUC), USA \\ Correspondence: Qais S. Ahmadi, Education Department, University of Maryland, University College (UMUC), \\ USA. E-mail: qais.ahmadi@faculty.umuc.edu
}

Received: June 9, 2017 Accepted: July 1, 2017 Online Published: July 3, 2017

doi: 10.5539/elt.v10n8p11 URL: http://doi.org/10.5539/elt.v10n8p11

\begin{abstract}
The Qatari college EFL (English as a Foreign Language) classroom is revisited in the author's second action research study conducted in the small Arabian Gulf country. The literature review allowed the author to gather themes that lead to this groundbreaking inquiry of the residual effects resulting from educational language reforms in the country. Due to the beginning stages of English as a medium of instruction (EMI) in Qatar, to the author's knowledge, no such research has taken place until now. The qualitative data collection method involved 11 focus group participants from the researcher's advanced-intermediate IEP (Intensive English Program) class that underwent a semi-structured interview. Results determine that, if given the choice, students would rather receive instruction in the Arabic medium instead of English to pursue undergraduate studies. The author offers additional research questions and recommendations in understanding the student perspective and why the EMI reforms have not been successful.
\end{abstract}

Keywords: EFL, English as a Medium of Instruction (EMI), language loss, colonialism, loss of culture, cultural identity, language policy, linguicide

\section{Introduction}

This paper examines the policy changes in the Arabian Gulf countries concerning the adoption of English Medium Instruction (EMI) in schools and higher education, and its potential effects according to the collected data. In the State of Qatar, for example, under the Education for a New Era (EFNE) reform, the ruling family has decreed the establishment of a bilingual education system as a means of transition to English as a medium of instruction. Under the leadership of the mother of the Emir, Her Highness Sheikha Moza Al-Misnad, the drive for English proficiency is projected to continue in order to realize the Qatar National Vision 2030 (Ellili-Cherif, 2014). In the governmental schools known as independent schools, Arab teachers lacking English proficiency have been expected to master the language in a very short time to teach English as a Foreign Language (EFL). The expectations, therefore, are undoubtedly high in all levels of the educational sector in Qatar, to meet the standards set by the aforementioned decree.

\section{Purpose}

The purpose of this article is to present an action research study on the apparent effects of EMI on the native language in the Arabian Gulf countries as a result of current educational reforms. Consequently, this research addresses the questions below.

Primary Question: How do adult male Qatari college students perceive their native language being under threat in an EFL context?

Secondary Questions:

How academically prepared do adult male Qatari college students feel in an English Medium Instruction (EMI) context, learning foundation English skills?

How do adult male Qatari college students feel about undergoing mandatory English language instruction in order to enter Arabic degree programs at their college in Qatar?

\section{Literature Review}

Before joining a college EFL classroom, Qatari students are now met with EMI in their independent schools, 
resulting from the educational reforms in their country. Interestingly, some parents of such children are not at all pleased with such reforms. For example, one parent in Ellili-Cherif's study (2014) declares that the EMI reform has brought great stress in Qatari households, forcing the parents to worry and seek out expensive English tutoring services at home. This practice adds financial burdens on parents. In the same study, another parent expresses her frustration concerning the educational reforms and supports the common view of how the independent schools have failed them. Even though the reforms are aimed at future success, parents are displeased with the change in their children's education.

On the other hand, Arab instructors who lack confidence in their English skills are now expected to provide instruction in EMI classrooms. More than 60 percent of teacher interviewees expressed their displeasure over the reforms in a recent study (Ellili-Cherif, 2014). More importantly, Ellili-Cherif also mentions they consider the reforms as a threat to Qatari culture and language.

The Omanis have seemingly embraced EMI with open arms and the parents of Omani schoolchildren are unabashed about introducing EMI to their children at an early age. In a recent study conducted by Tekin (2015) at Sultan Qaboos University in Oman, the findings reveal that Omani parents are very keen on developing the English language skills of their children from an early age in order to be successful in the future. Equating Anglicism with future success is now a common trend at the administrative level in the Arabian Gulf, and Tekin's article clearly brings it to light. In Oman, education counts for $24 \%$ of government expenses (Tekin, 2015). Such a major investment is a testament of the government's commitment to educating its people, and EFL now serves the Arabian Gulf as a language of advancement/higher education.

Kuwait is another Gulf country that has been providing EFL instruction since 1994, as the government believes that it leads to better learning outcomes and advancement (Alrabah, Wu, Alotaibi, \& Aldaihani, 2016). Like Oman, English in Kuwait begins in the primary level and continues on to higher learning. The expectations increase with every grade level with proficiency being the aim.

The Kingdom of Saudi Arabia is also aiming to establish EMI in its schools and places of higher learning. Sharing a common belief with neighboring countries, Saudi Arabia believes that English is an international language and has invested substantially to provide its instruction to nationals (Khan, 2011). As the country with the largest land mass in the region, it has to face more challenges than the smaller Gulf countries in establishing EMI.

Since this topic is still being explored, not many articles could be cited that represent the context the researcher has studied. Hence, this is one of the reasons why it was necessary to conduct this study. However, the references found are adapted to the author's research due to their generalizability.

\section{Methodology}

For this study, informative qualitative data was collected using a semi-structured interview. Themes such as lingua franca, language rights, language loss, colonialism, loss of culture, cultural identity, and language policy were all taken into account. Students' perception, feeling, frustration, and despair were considered as data. A semi-structured focus group interview was the main data collection method used to investigate the primary question: Describe how native Qatari students perceive their native language being under threat within an EFL context. This information is important to gather for the purpose of determining the possible factors leading to linguicide (Skutnabb-Kangas, 2000). The interview allowed student participants to elaborate on their survey responses and voice their feelings (see Appendix). The focus group enabled the students to express their perception, feeling, frustration, and despair since they may have not had the opportunity to do so before. The final method of collecting data was through a narrative journal. This enabled the teacher to formally record the in-class observations and reflections (Mills, 2014).

The participants of this action research were eleven Qatari advanced-intermediate male students in the foundation English language learning program. They varied in age and field of employment. The research took place at a college IEP (Intensive English Program) in the state of Qatar.

\section{Results}

This part of the paper portrays the study results. Table 1 and the list below reveal the study findings. 
Table 1. Themes and categories emergent from native Qatari college student focus group interview

\begin{tabular}{ll}
\hline Themes/Categories & Frequency of Code \\
\hline English as lingua franca of the world & 3 \\
British imperialism & 5 \\
Requiring Arabic instruction to foreigners & 4 \\
Arabic as religious/heritage language & 7 \\
EMI as waste of time & 7 \\
\hline
\end{tabular}

List of Participants' Beliefs Regarding EMI:

1. Many non-Arab foreigners live in Qatar, so English is used to communicate with them.

2. English is the language of communication, business, technology, tourism, as well as World Cup 2022, and the language of the future.

3. English only helps with ordering meals at restaurants.

4. English was brought over by the British in the 1930s and has been in Qatar ever since. The national telecommunications company was British owned and even the head of the national cable company was a British man.

5. Non-Arabic speaking foreigners should be required to learn Arabic when living in Qatar similar to how Qataris in Japan learn Japanese.

6. As an Arab-Muslim, the Arabic language is a source of pride, and it must never be forgotten. It should be the language of instruction, rather than English.

\section{Discussion}

There are ambitious visions and missions that the Arabian Gulf countries have set along with a fair share of obstacles. For one, are these countries prepared to provide EFL instruction in order to meet their objectives? Decisions are made that result in new curricula. Schools, colleges, and universities are also established for the sake of EMI. However, another question that begs to be answered is, do the nationals want to undergo the learning and acquisition of English? There may be exceptions like the parents mentioned in Tekin's study (2015).

On the other hand, EMI can also be a cause for oppressing students in their own country (Ahmadi, 2015). The Arabian Peninsula is no stranger to conquest, and the British Empire's mark can be witnessed to this day like the British Council. In her study, an interviewee suggested to Ellili-Cherif (2014) that the all teachers lacking English proficiency in Qatar should enroll in the British Council for language improvement. The British Council (BC) has long established itself as the center of teaching English in Doha, providing tests like IELTS. Needless to say, the British Council has marketed itself as the best for profit English language program. Qataris have come to know the $\mathrm{BC}$ as a center they can trust since word-of-mouth still holds more weight than any other form of communication. However, what the interviewee did not mention is that the $\mathrm{BC}$ is more of a provider for English for Specific Purposes (ESP) or IELTS exam preparation and so on. Unlike the Qatari college that has served as this study's setting, the BC is not a bachelor degree granting institution. The IEP program at the Qatari college requires full registration, and enrollment by the students follows an academic calendar, accepting students that commit to the program's attendance policy. Should the student exceed 10 contact hours of absences, then she/he will be dropped from the program with only one more chance to be reinstated. If a student fails during the second enrollment, then she/he will not be allowed to re-enroll for classes at the college. The major condition for enrollment is to pass the IEP program successfully. These are all ambitious expectations for the nationals, but the barriers must also be taken into account when promoting a vision or mission nationwide.

In answering the question of whether or not Qatari students want to learn English, the author personally has witnessed the bitterness most Qatari students express in the IEP program. They see it as an obstacle to earning their Arabic degrees that will result in a higher paying salary. Aside from financially driven pursuits, students have also expressed fear of losing their culture. This sentiment is mirrored in Ellili-Cherif and Romanowski's study (2013) as well in the form of an interviewee's suspicion of the English language entering his country to replace his native language - Arabic. This suspicion is not baseless since the majority of the Arabian Gulf countries host an expatriate labor and professional force that do not speak Arabic. Therefore, the nationals of these Arabian Gulf countries find themselves in a bilingual or even a multilingual environment whether they are 
actually aware of it or not.

\section{Conclusion}

According to recent literature, the majority of nationals affected by the sudden change in the linguistic landscape would not want EMI in their country if ever asked to choose. In the case of one Qatari parent, his child did academically better before the mandatory inclusion of EMI in the governmental schools. Thus, this parent considers EMI to be the cause of his child's academic failure (Ellili-Cherif, 2014). English is completely foreign when compared to Arabic. Both are from different language families, and grammar translation is not possible. Although some students may view it as a novelty language useful for travel and dining, not every Arabian Gulf country welcomes EMI, and many Qataris believe that it is a waste of time and even a threat to their mother tongue. Most of the author's students in his previous position in Saudi Arabia even predicted the death of the Arabic language as a result of EFL instruction (Ahmadi, 2015). Consequently, the question arises: how can Arabic be protected from foreign languages that have entered these countries? The author suggests analyzing the needs of the population first. Instead of sweeping changes in language policy, a needs analysis should be taken so that EMI is provided to those who willingly choose it. Since this has not been done, the attitudes towards EFL may continue to become bitter. The more bitter the students, the more challenges in student retention. It may serve though as a solution by allowing nationals as stakeholders in educational reforms.

\section{References}

Ahmadi, Q. S. (2015). Othering in the EFL classroom: An action research study. International Journal of Humanities and Cultural Studies, 1(4), 439-469.

Alrabah, S., Wu, S., Alotaibi, A. M., \& Aldaihani, H. A. (2016). English teachers' use of learners' L1 (Arabic) in college classrooms in Kuwait. English Language Teaching, 9(1), 1-11. http://dx.doi.org/10.5539/elt.v9n1p1

Ellili-Cherif, M., \& Romanowski, M. (2013). Education for a new era: Stakeholders' perception of Qatari education reform. International Journal of Education Policy and Leadership, 8(6), 1-17. http://dx.doi.org/10.13140/2.1.4032.3203

Ellili-Cherif, M. (2014). Integrated language and content instruction in Qatar independent schools: Teachers' perspectives. Teacher Development, 18(2), 211-228. https://doi.org/10.1080/13664530.2014.900819

Khan, I. A. (2011). The teacher of English: Pedagogic relevance in Saudi Arabia. English Language Teaching, 4(2), 112-120. https://doi.org/10.5539/elt.v4n2p112

Mills, G. E. (2014). Action Research: A Guide for the Teacher Researcher. Essex: Pearson Education Limited.

Skutnabb-Kangas, T. (2000). Linguistic genocide in education, or worldwide diversity and human rights? Mahwah, N.J: L. Erlbaum Associates. https://doi.org/10.1075/lplp.29.2.08bre

Tekin A. (2015). Early EFL education is on the rise in Oman: A qualitative inquiry of parental beliefs about early EFL learning. English Language Teaching, 8(2), 35-43. http://dx.doi.org/10.5539/elt.v8n2p35

\section{Appendix: Interview Questions for Participating Students}

Q1. Why is English used in your country?

Focus group student \#1: Because, uh, we have many different cultures [that] live with us.

Focus group student \#2: It is the language of a trade, and also of the facilities in Qatar use the English language. Because in Hamad city we have multicultures. Some jobs need English language: doctors, engineers.

Focus group student \#3: Some jobs, yeah, like customer service.

Focus group student \#4: Because it is [the] language of the future.

Focus group student \#3: Right now, [English] is the best language in the world!

Focus group student \#2: It is worldwide English.

Q2. How long has it been spoken here?

Focus group student \#1: From, uh, (asks other students the for translation of الاستعمار)

Focus group student \#2: Since the British. Since 1930, maybe.

Focus group student \#1: Yes, yes, teacher, 1930.

Focus group student \#2: They [British] was traveling around Qatar. Also, [to the] north of Qatar. They came to 
my grandfather and they take pictures. I see them in 1978, still.

Focus group student \#5: The manager of Qatar cable was British.

Q3. Who brought English to your country?

All focus group students: The British, yes.

Focus group student \#2: And Q-Tel also, [now] Ooredoo was a British company before.

Q4. How long do you have to study it?

Focus group student \#3: All my life.

Focus group student \#1: (asks other students the for translation of الاعتراف)

Focus group student \#1: Because, teacher, in different countries like Japan, U.S., Britain, Australia. [If] I go there to study or for job, I must learn the language of [those] countries. And, uh, here in Doha, we must do the same. My brother works in Japan. He must learn [Japanese] in university [for] two years. No English. [At] his work, [he] must know the language (Japanese) for the country.

Focus group student \#3: The government didn't put the rule for this one [here in Qatar] (referring to focus group student \#1's comment.

Focus group student \#2: Rule is good to encourage them [non-Arabic speakers] to learn Arabic.

Focus group student \#6: Sometimes, I take [a] course in computers in English language.

Focus group student \#1: Because teacher, uh, I am Muslim, Arabic-Muslim, uh, (asks for translation of the Arabic word افتخر).

Focus group student \#2: Proud.

Focus group student \#1: I am [proud] to speak Arabic a long time.

Focus group student \#3: (responding to focus group student \#1's comment) Some Muslims, uh, can read Qur'an, but they cannot speak Arabic.

Focus group student \#1: Where [is] this?

Other focus group students: India, Iran, Pakistan, Indonesia, Malaysia.

Focus group student \#1: We must know English to complete the study. [For] this reason [only]. And here [this college], all start in English level to level 3 and continue in Arabic track. We don't to continue learn English.

Focus group student \#6: Teacher, if you learn in English track, you [will be] confuse[d] in [your] study and you cannot finish the subject. You cannot understand. I think like this if you go to Arabic track maybe it [is] easy for us.

Focus group student \#2: Because they want to save time. They don’t want to waste time. They want to finish in two years.

Focus group student \#7: Because [that] is academic English. There are problems in academic English. They [Qatari students] feel it is very hard.

Q5. What is the difference between someone that knows English as opposed to one that does not?

Focus group student \#2: Big difference. He can get many sources from the English language from media, from other things. Also, even studying in academic levels to finish his study, he can get more research. Because, uh, in English you have many sources, unlike Arabic.

Focus group student \#3: Many skills you get [from English]. If you, you, know English, you make your life easy. Why? Because when you traveling, you go outside your country, you can (asks others for translation of التعاون) with other people.

Focus group student \#8: Deal [cooperate]. (Asking focus group student \#3) Maybe some Muslim traveling outside. He just only use the restaurant [menu]. (Has internal discussion in Arabic about Qataris that do not need English to travel).

Focus group student \#2: (Translates the internal discussion) Mr. Qais, they [are] saying, we know English. But it's different [than what they say]. [Learning English] you improve yourself in your daily life, your work,

Focus group student \#8: Some person [they] thinking [if a] person speaking English very well he is smart.

Focus group student \#3: Not smart, not smart! It's English for your life, not for you're smart or you're not smart. 
Focus group student \#2: It's for your own benefit [is what] he says.

Focus group student \#8: I think [the] first language [should] be [the] language [of] your mother.

Focus group student \#2: You gain a lot when you speak another language.

Focus group student \#6: It's good to know it in travel, teacher.

Focus group student \#9: Even in your [own] country!

Focus group student \#10: Teacher, there is the World Cup.

Focus group student \#11: Ok, teacher, our language it's Arabic. But we must study other languages.

Focus group student \#1: For a long time, no, teacher. Two course[s] of English or four course[s] [to] know the basics for English and الستّلامُ عليخّزم (as-salaamu alaykum').

Focus group student \#11: [English] [is] still growing, teacher. Because from 80 years ago 'til this year, the English language in Doha [is] still weak.

Focus group student \#2: It's going to improve!

Focus group student \#1: Teacher, this [is] my language (Arabic) - the language of the Qur'an. Arabic Muslim Qatari must to know Arabic, and finished.

Focus group student \#11: No, my question is, will [you] forget Arabic?

Focus group student \#1: Of course not!

Focus group student \#11: You can't!

Focus group student \#3: Some people forget Arabic.

Focus group student \#2: Mr. Qais, we know that English is very important. We must study it. Arabic is important, also.

Focus group student \#11: It's not only English, guys. Other languages.

Q6. Where do you have to use English in your country?

Focus group student \#8: In [referring only to his respected college]

Most focus group students: In restaurants.

Some focus group students: At work.

Focus group student \#1: [As] for me, teacher, [this class] is enough.

Focus group student \#8: Some students said they speak English at work, but I don't think so they use it at work.

Q7. Where do you not have to use English in your country?

Focus group student \#1: Mosque

Focus group student \#2: Some jobs.

Most focus group students: The police

Q8. Is it better to know or not know English? Why/Why not?

Focus group student \#3: It's better [to know].

Focus group student \#1: Why?

Focus group student \#2: Teacher, if some tourists come to my country, I can deal with him.

Focus group student 8: Is this for your job?

Q9. Which language will be used when hosting the World Cup? Why?

Most focus group students: English

Focus group student \#11: (Telling other focus group members that he does not want the World Cup to take place in Qatar).

Focus group student \#6: Why?

Focus group student \#8: Teacher!

Focus group student \#11: Teacher! They will destroy.

Focus group student \#2: No, uh, it's a good thing, but there is some bad things. 
Focus group student \#11: They will destroy our country, teacher. Every super market needs to sell alcohol. They will need to sell alcohol in the stadium.

Focus group student \#1 and 3: No, no, in the stadium, only. Outside, no.

Q10. What do you think about the person who does not want to learn English?

Focus group student \#11: He has a closed mind.

Focus group student \#2: You have to be open to other cultures. Globalization.

Focus group student \#8: العشرة المبشرون بالجنة

Focus group student \#1: He [is] saying that the ten [companions] that were promised Jannah (paradise) were Arabic speakers, not English.

Q11. Which nationals speak English? Why?

Focus group student \#2: Educated people. In daily life.

Focus group student \#11: There are some Qataris that speak English at home.

\section{Copyrights}

Copyright for this article is retained by the author(s), with first publication rights granted to the journal.

This is an open-access article distributed under the terms and conditions of the Creative Commons Attribution license (http://creativecommons.org/licenses/by/4.0/). 